\title{
Shared Visions: Professional Development for Teacher Education Faculty
}

\author{
Leslie Hall, Clint Fisher, Sandra Musanti, \\ Don Halquist, Matt Magnuson, and Darcy Simmons-Klarer \\ University of New Mexico, Albuquerque, NM, USA
}

Idhall@unm.edu, cfisher@unm.edu, smusanti@unm.edu,
donh@unm.edu,

\begin{abstract}
This paper discusses a professional development program in the area of technology integration for teacher education faculty. The program was funded by a Preparing Tomorrow's Teachers This initiative involved one assistant professor of educational technology and five doctoral students as Tech Guides as the professional development team. Twenty-five faculty members who teach methods courses for licensure participated in the program. Each graduate student mentored five faculty members. The design of the professional development relied on the faculty members as professional educators to co-design the program with the professional development team. We discuss some of our insights gained from this three-year initiative and suggest ways in which this and similar programs could be supported and institutionalized in colleges of education.
\end{abstract}

Keywords: teacher education, professional development, technology integration, mentoring, graduate students

\section{Introduction}

Like each new technology that preceded them-radio, film, and television- computers entered U.S. schools with promises to transform educational practices. In 1985, Apple Computer, Inc. began an innovative program, Apple Classrooms of Tomorrow (ACOT), which provided teachers, schools, and students full access to computer technology. One goal of the ACOT program was to improve understanding of how classrooms and learning would change when the latest computer technology was paired with accomplished instruction. In the mid- to late-1980's, additional large-scale funding for the purchase of hardware and software became available from private and public sources. In most funding available at this time, few provisions were made for the professional development of K-12 teachers in the area of learning to integrate technology into classroom practices. Early professional development that did occur tended to be short-term and focused on technology skills. Teachers were expected to change their teaching practices with little or no sustained support.

In the 1990's, computers had not fundamentally changed the educational experiences of most American children. In 1995, the Office of Technology As-

Material published as part of these proceedings, either on-line or in print, is copyrighted by Informing Science. Permission to make digital or paper copy of part or all of these works for personal or classroom use is granted without fee provided that the copies are not made or distributed for profit or commercial advantage AND that copies 1) bear this notice in full and 2) give the full citation on the first page. It is permissible to abstract these works so long as credit is given. To copy in all other cases or to republish or to post on a server or to redistribute to lists requires specific permission from the publisher at Publiste@entiomingscience.org sessment, part of the U.S. Department of Education, issued a report, "Teachers and Technology: Making the Connection," revealing the under-preparation of preservice teachers in the area of technology. The report stated that most teacher preparation programs focused on teaching about technology, not teaching with technology. Also, in 1995, the U.S. Department of Education offered new grant opportunities 
through "Technology Innovation Challenge Grants" to fund school district-business partnerships to apply unique uses of technology toward learning improvement and systemic education reform.

Several events in 1996 established the need for more professional development opportunities in the area of technology integration at all levels. The Department of Education established the "Technology Literacy Challenge Fund" to help states increase their potential to integrate educational technology into the daily practices in K-12 classrooms. The National Commission on Teaching \& America's Future released "What Matters Most: Teaching for America's Future." Two pieces of this report impacted teacher education. First was the challenge for teacher educators to model the use of new technologies in teaching and assessment. The other was the recommendation that all colleges of education be accredited through NCATE. "Technology and the Professional Teacher: Preparing for the 21st Century Classroom" was released by NCATE. This report acknowledged the potential impact NCATE could have on preservice teacher education programs by requiring that new teachers know how to competently use educational technology.

\section{In 1999, the U.S. Department of Education opened competition for "Preparing Tomorrow's}

Teachers to Use Technology" (PT3) grants aimed at supporting reforms in teacher preparation programs that would foster the preparation of new teachers familiar with and adept in integrating technology into K12 learning environments (U.S. Department of Education, 2001).

PT3 grants presented a unique opportunity in the area of professional development in higher education. This was the first large-scale initiative intended to assist college of education faculty in integrating computer-based technology into preservice teacher education courses. Considine (2000) points out that

far from being unexpected or unanticipated, technology's failure to transform education is highly predictable based on the fact that for the most part, teachers have experienced the changes associated with technology, as something that happens to them, not through them (p. 300, emphasis in original).

In October 1999, our PT3 grant proposal, Shared Visions, received funding from the U.S. Department of Education. We realized that if the experiences of preservice teachers and their future students were to change, technology integration in teacher education had to happen through our faculty, not to them. Our teacher education faculty members are master teachers who successfully blend theory and practice. We relied on them as educators to co-design their professional development in the area of technology integration. Our purpose here is to use insights gained from our professional development initiative that will contribute to research in the area of designing professional development for teacher education faculty.

Methods faculty in our College regularly grounded their courses in constructivism and socio-political issues of education, but they did not have the knowledge and skills necessary to connect these to computerbased learning activities. Our preservice teachers generally saw technology integration as important only in the one microcomputer course required for licensure. Shared Visions provided the professional development funding to help twenty-five of our teacher education faculty explore the possibilities of computers as content and pedagogical tools in their various disciplines.

Our intention in this professional development initiative was to depart from traditional professional development for K-12 teachers. They have often been taught a piece of software and then expected to enthusiastically integrate it with few opportunities for additional coaching, scaffolding, or reflection. In our professional development program, we attempted to alter this phenomenon by relying on our faculty participants as content area specialists and teacher educators to help us understand how different types of software can contribute to conceptual learning and to instructional strategies. As educational technologists, we seldom ask content experts to tell us how a certain type of software could enhance learning in their disciplines. Not every type of software fosters conceptual learning in every subject area. Our first goal was to expose the faculty participants to many types of tool software. Through modeling, coaching, scaffolding and reflection, they explored which types of software and what kinds of activities were appropriate for 
Hall, Fisher, Musanti, Halquist, Magnuson, \& Simmons-Klarer

nurturing changes in instructional strategies for their disciplines.

In this paper, we briefly discuss the design of our professional development, describe the professional development team, highlight some insights gained from work with the faculty, and conclude with suggestions for next steps in professional development for teacher education faculty in technology integration.

\section{Design Principles}

Two research studies guided our design of professional development in the area of technology integration for teacher education faculty. In 2000, the International Society for Technology in Education established national educational technology standards for teachers (ISTE NETS). Our professional development team used these to assess our design and to adjust it whenever necessary.

Long-term support is key to teacher change. Teachers need time to consider how to use computers in the classroom; and, they must have long-term expectations for learning to use the technology (Kerr, 1991). The Apple Classrooms of Tomorrow (ACOT) model of professional development as a continuous process that encompasses teaching practice and promotes a progressive integration of various technology tools offered valuable guiding principles for our professional development model. Studies from the ACOT classrooms yielded a stage theory of technology integration that illustrates the process beginning with entry, moving through adoption, adaptation, and appropriation, and sometimes reaching innovation (Sandholtz, Ringstaff \& Dwyer, 1997). This stage theory helped us to understand some of the actions and reactions of our faculty participants as they rethought their methods courses.

The notion of graduate students mentoring professors became a central piece of our professional development design. We envisioned the potential of graduate students mentoring and supporting the on-going technology learning process of the faculty participants while collaboratively designing lessons for faculty participants' respective courses-a vision that directly aligns with the Generation Y model. Generation Y (Generation YES, 2000), a U.S. Department of Education Technology Innovation Challenge Grant (TICG), funded training for secondary students to build and to maintain networks, and to assist teachers with technology-integration classroom activities. Following a one-semester course, secondary students mentored one of their teachers during the school day. The result - a teaching unit integrating technology co-designed by the teacher and the GenY student. This model proved to be so successful that Generation Y became a yearlong elementary program for students in grades four and five. This research inspired our partnering of graduate students and methods faculty for the exploration of technology integration in preservice teacher education.

The ISTE NETS, established in 2000, served as another tool in assessing our professional development. Through Shared Visions, we addressed all areas of the National Educational Technology Standards for teachers: technology operations and concepts; planning and designing learning experiences; teaching, learning, and the curriculum; assessment and evaluation; productivity and professional practice; and social, ethical, legal, and human issues.

Utilizing ACOT (Sandholtz, Ringstaff and Dwyer, 1997) and Generation Y (Yocam, 1996) studies, ISTE standards for teachers, and the insights provided by early research on professional development for technology integration in K-12 environments (Kerr, 1991; Hadley \& Sheingold, 1993), we designed a model based on the ideas of continuous support and collaboration, graduate student mentoring, and contextualized technology experiences.

\section{Our Professional Development Team and Participants}

Our PT3 professional development team consisted of one assistant professor of educational technology, referred to as the Professional Development Coordinator, and five doctoral students, referred to as Tech Guides. All were affiliated with the two primary teacher education departments in the College of Educa- 
tion. Based on the GenY model, each Tech Guide assisted five faculty members with technical support, one-on-one instruction, developing and facilitating technology integration experiences, and evaluating preservice teachers' learning.

All five Tech Guides were risk-takers, used computer-based technology for personal and professional practice, and had classroom teaching experience. In addition, each brought unique expertise and knowledge to the professional development team. The five Tech Guides immediately formed a close-knit group where strengths and weaknesses were freely shared. In retrospect, two circumstances contributed to this closeness. Only one of the five Tech Guides was in an educational technology doctoral program. His knowledge and experience were highly valued by the others as they engaged in just-in-time learning. Location turned out to be another factor defining the Tech Guides as a group. All five shared one office, which facilitated socializing, and group problem solving. They came to rely on one another's strengths while building expertise with various pieces of software, developing integration strategies, and coping with unpredictable faculty.

Twenty-five faculty members who taught methods courses for licensure were invited to participate in the professional development. We experienced some turnover in participants due to sabbatical leaves, departures from the university, leaves of absence, and withdrawals from grant activities. Over the three-year life of Shared Visions, we served 30 faculty with 19 participating throughout the grant. We provided faculty participants opportunities to observe, to engage in, and to invent or discover strategies for integrating tool software into their methods courses (Collins, 1989).

\section{Insights Gained from Our Work}

The insights discussed here were gained through on-going reflection on our professional practices as we collaborated with the faculty in developing a model of professional development. To gain these insights required that we step back and reflect on what we were doing, where we wanted to go, and what faculty participants thought about this developmental process.

As the professional development team, we instituted on-going reflection during weekly team meetings as well as in the conversations that we facilitated with the faculty participants. We took advantage of every opportunity to discuss what was working in the scope of our collaborative work. Workshops, reading discussions, and one-on-one faculty encounters between Tech Guides and professors were seen as openings to reflect on our model and to make needed changes within that model to fit the needs of the faculty.

In order to appropriate time for reflection, we created reflective spaces in the form of interviews, conversations during one-on-one tutoring sessions, and planned discussions for faculty participants to share insights with us about our model of professional development. Opening these reflective spaces allowed us to learn from the faculty how they were experiencing the implementation of the professional development, the unique needs of each individual as they developed a personal vision of technology integration, and the impact of conditions of work on the success of our model. Insights cited here and discussed below aided us in continually reassessing our roles as the professional development team. These insights facilitated realignment of our professional development model in order to fit the needs of the faculty throughout the grant period.

\section{Insights}

1. Any process aimed at changing teaching practices must be sustained and supported over time.

2. Mentoring relationships between Tech Guides and faculty promote collaboration as a central piece in the co-development of classroom activities.

3. Relationships based on comfort foster collaboration and growth. 
4. Small group conversations and continuous interaction positively impact the design of professional development.

5. Each faculty member's philosophy of education and teaching style must be respected in the process of integrating technology.

6. Incentives promote interest and motivation, but institutional pressures will contribute to lack of participation.

\section{Discussion of Insights}

In this section we discuss each of the insights and some events leading to them.

\section{Insight 1}

\section{Any process aimed at changing teaching practices must be sustained and sup- ported over time.}

The twenty-five faculty participants had varying degrees of motivation and commitment to their own and their preservice teachers' learning with and about computer integration. Support during the process of integrating technology came in two forms: hardware/technical and professional. The first was equipment including laptop computers, access to peripherals, and technical maintenance. Professional support included collaboration with Tech Guides, the Professional Development Coordinator, and other faculty participants, assisting the faculty in learning new pieces of software and in planning integration activities. The Table 1 shows the responsibilities of all partners in our design.

Among the main characteristics of professional development are the opportunities for learning in context, discipline inquiry, and the creation of collegial and collaborative networks (Lieberman, 2000). Within this context, there is a need to strengthen teachers' possibilities for contextualized learning that contributes to a

\begin{tabular}{|c|c|c|}
\hline $\begin{array}{c}\text { Faculty Development } \\
\text { Coordinator }\end{array}$ & $\begin{array}{c}\text { Tech Guides } \\
\text { (Graduate Students) }\end{array}$ & $\begin{array}{c}\text { Faculty } \\
\text { Participants }\end{array}$ \\
\hline $\begin{array}{l}\text { *Work with the principle } \\
\text { investigator and the grant } \\
\text { coordinator } \\
\text { *Recommend graduate stu- } \\
\text { dents for the position of Tech } \\
\text { Guide } \\
\text { *Convene weekly planning } \\
\text { meetings with the Tech } \\
\text { Guides and grant coordinator } \\
\text { *Oversee data collection } \\
\text { *Lead workshops and read- } \\
\text { ing discussions } \\
\text { *Co-plan workshops with } \\
\text { Tech Guides } \\
\text { *Recommend materials for } \\
\text { purchase }\end{array}$ & $\begin{array}{l}\text { *Work one-on-one with } 5 \text { as- } \\
\text { signed faculty } \\
\text { *Co-plan workshops } \\
\text { *Prepare materials for work- } \\
\text { shops and reading discussions } \\
\text { *Co-plan technology integra- } \\
\text { tion activities with faculty } \\
\text { *Lead or facilitate technology } \\
\text { integration activities } \\
\text { *Gather data } \\
\text { *Attend weekly planning meet- } \\
\text { ings } \\
\text { *Keep a researcher log } \\
\text { *Recommend materials for } \\
\text { purchase }\end{array}$ & $\begin{array}{l}\text { *Work one-on-one with } \\
\text { assigned Tech Guide } \\
\text { *Co-plan technology inte- } \\
\text { gration activities with Tech } \\
\text { Guide } \\
\text { *Lead, facilitate, or partici- } \\
\text { pate in technology integra- } \\
\text { tion activities } \\
\text { *Provide data as requested } \\
\text { *Attend workshops } \\
\text { *Participate in reading dis- } \\
\text { cussions } \\
\text { *Recommend materials for } \\
\text { purchase }\end{array}$ \\
\hline
\end{tabular}

Table 1: Responsibilities of Professional Development Team and Faculty Participants 
deeper understanding of teaching practices and student learning.

We found that the same conditions that support technology-integrating teachers support technologyintegrating faculty (Kerr, 1991 and Hadley \& Sheingold, 1993). Examples include motivation and commitment to learning and development; support from colleagues; access to technology; and enough time.

I think the Shared Visions has been a very good program for the faculty members and has afforded me the opportunity to do some exploring and development, [has provided] professional development for myself that otherwise would have been much, much harder for me to do. So I've appreciated that. I know that I haven't always been able to focus on all the various topics. (Teresa, Science Education)

Research points to the importance of sustained professional development for long-term changes in instruction (Lieberman, 2000; Stein and Silver 1999; and Sprinthall, Reiman, and Thies-Sprinthall, 1996). Designers of professional development for teacher educators must consider the complexity and unique requirements of teaching in higher education in order to create valid and suitable learning situations that address the unique needs of those who work with preservice teachers.

Tech Guides were assigned five faculty members each. The partnering of Tech Guides and faculty participants was designed for their mutual benefit. Each Tech Guide was pursuing a doctoral degree in education. Working with faculty members gave them insider knowledge (Cochran-Smith \& Lytel, 1993) into rethinking, redesigning, and teaching preservice methods courses.

Each Tech Guide had personal traits, unique areas of expertise, and experiences in educational settings that made them particularly qualified to share in the rethinking, redesigning, and teaching of methods courses with their assigned faculty participants.

Don Halquist, had a background in graphic design as well as a degree in early childhood education and primary grade teaching experience. He became a great collaborator with faculty members in early childhood education. Sandra Musanti's extensive professional development experience and her work in special education made her a wonderful resource for Special Education faculty. Darcy Simmons-Klarer was very organized and task-oriented plus experiences integrating technology into her own teaching of elementary science methods courses provided practical knowledge for faculty participants in science education and mathematics education. Matt Magnuson possessed better than average skills in software and hardware troubleshooting. Matt's fluency in Spanish and his work in ESL and community adult education made him a natural choice for working with the bilingual/ESL faculty. Clint Fisher was the only Tech Guide working toward a doctoral degree in educational technology. Clint worked with faculty in physical education and Indian education where his familiarity with hardware and software tools and his broad background in integrating multiple technologies in diverse settings was extremely useful. The faculty participants received invaluable technical and professional support from all Tech Guides.

Coaching during one-on-one office sessions and in monthly workshops helped bring faculty expertise with the software to higher levels. Together the professional development team and the faculty explored concept mapping with Inspiration; hypermedia/multimedia with HyperStudio, PowerPoint and Kid Pix; advanced Web searching and WebQuests with various search engines; video editing with iMovie; and desktop publishing with AppleWorks.

\section{Insight 2}

\section{Mentoring relationships between Tech Guides and faculty promote collaboration as a central piece in the co-development of classroom activities.}

The Tech Guide role was defined as a mentoring and collaborative relationship between graduate students 
and faculty. The protean nature of the role resulted from a three-year construction involving joint work with the faculty as well as constant conversations among the Tech Guides, the Professional Development Coordinator, and the faculty participants. These conversations involved the definition of mentoring as a complex and interactive process with the faculty through which the Tech Guides would share their technological expertise with the faculty by establishing a relationship based on mutuality, respect, compatibility, collegiality, and understanding. As the professional development team, we agreed that a collaborative approach to mentoring was needed in order to reach effective ways of working together. Ever cognizant that we wanted this professional development to happen through our faculty, not to our faculty, we were "aware of the irony of imposing collaborative norms" (Johnston, 1997, p. 42, emphasis in the original). We believed that "it is through joint activities and partnerships that we confront our shifting realities and search for new solutions" (John Steiner, 2000, p. 3).

One faculty participant reflected on collaboration during an interview, "I look at it as working to promote social interaction, and then the collaboration will grow out of it. But forcing collaboration, I've always lost in this situation." (Penny, English Education)

As a team, we worked on building relationships that promote collaborative efforts while opening spaces to mentor faculty into their own technological development. Of course, some experiences were more successful than others. We considered the most successful experiences to be those with genuine collaboration between Tech Guide and faculty member. This occurred when each acknowledged the strengths and contributions of the other. Success included planning and implementing the integration of some technological piece into their method courses in a way that fit the preservice teachers' needs, the course objectives for teaching pedagogies appropriate for the given content area, and the faculty member's teaching style. One Tech Guide reflected on her relationship with a special education faculty member as they initiated their work together:

Working together, Elizabeth and I reflected on the need to include technology as a teaching tool in her classes. She began to develop ideas on how to use [Inspiration and Web Quests] to teach to preservice teachers so she could model for them different ways of integration. As a result of our work together, she modified her previous teaching of educational software. ... It was very important for the students to understand the connection between the technology piece that we were introducing, the content they were learning, their own teaching experience and the courses' assignments. (Sandra, Tech Guide)

Integration activities were based on the faculty member's expertise with any given piece of software that informed their understanding of its potential as a learning tool. During the second year of the grant, 200001, Tech Guides led the technology integration activities providing a conceptual model for the faculty member and the preservice teachers in the class. During the third and final year, 2001-02, the roles of faculty and Tech Guides reversed. While continuing to collaborate on the planning, now the faculty participants were expected to lead the technology integration activities with support from the Tech Guides.

One of the advantages of working with methods faculty in the Shared Visions project was their expertise in content knowledge and pedagogy. Like Rosenholtz's (1989) 'moving' as opposed to 'stuck' teachers, these faculty members recognized that they needed help to effectively integrate computer-based technologies. They had to learn from the Tech Guides and one another. Asking for help was not seen as a sign of incompetence, but of inexperience.

\section{Insight 3}

\section{Relationships based on comfort foster collaboration and growth.}

From the earliest days of writing the PT3 grant, we knew the success of our professional development initiative depended on the relationships between the Tech Guides and faculty participants. The obvious 
choices for Tech Guides would have been graduate students highly skilled in computer troubleshooting and adept at using multiple pieces of software. However, our focus was not on developing the technical skills of the faculty. Understanding that our faculty participants are master teachers, we wanted to expose them to a number of pieces of open-ended software, allow them ample time and support to become familiar with the software, and finally, ask them to tell us how they would use these pieces of software when working with preservice teachers in learning content and/or pedagogy. The most important knowledge of the Tech Guides, therefore, was their lived experience of classroom teaching. We reasoned that the Tech Guides could engage in just-in-time learning with the hardware and software to compensate for lack of skills, but nothing could compensate for lack of teaching experience. As one faculty member stated, "I sense a mutual respect toward educating young children in ways that bring out their creative potential." (Baji, Early Childhood)

Another important aspect of building productive mentoring relationships with faculty was to help them grow in their levels of comfort with using and integrating technology. One faculty participant explained her own sense of inadequacy and how this might become an obstacle when deciding to integrate technology

I don't want to... my biggest reservation is standing up in front of the class teaching something and getting stuck and lost... and I know its just fine to do that but that its always, you know-teachers are supposed to know everything and I think that it's really good that they don't and that we struggle [in front of our students]. (Liz, Special Education)

We came to understand how important comfort is for the growth of each individual. We used a selfreporting survey on stages of adoption to track each faculty member's changes in comfort with and confidence in using technology. This survey included six stages of technology adoption adapted from the ACOT research (Sandholtz, Ringstaff \& Dwyer, 1997):

- Awareness- I am aware that technology exists but have not used it, perhaps I'm even avoiding it.

- Learning the Process - I am currently trying to learn the basics. I am sometimes frustrated using computers. I lack confidence when using computers.

- Understanding and Applications - I am beginning to understand the process of using technology and can think of specific tasks in which it might be useful.

- Familiarity and Confidence - I am gaining a sense of confidence in using the computer for specific tasks. I am starting to feel comfortable using the computer.

- Adaptation to Other Contexts - I think about the computer as a tool to help me and am no longer concerned about it as technology. I can use it in many applications and as an instructional aid.

- Creative Applications to New Contexts - I can apply what I know about technology in the classroom. I am able to use it as an instructional tool and integrate it as an instructional tool. I am able to integrate technology into the curriculum.

In Fall 2000, survey results showed that more than $50 \%$ of the 25 faculty positioned themselves in the second stage, learning the process. They assessed themselves as learning the basics, being sometimes frustrated with the computers, and lacking enough confidence to use computers in their own teaching. None of the faculty positioned themselves in the final stage, creative applications to new contexts. Few thought that they would be able to use many applications and apply them as instructional tools.

By Spring 2001, on the same survey instrument, 55\% of the faculty positioned themselves in the final stage, indicating they believed they could apply creative applications to new contexts. So, at the end of the first full year of this professional development initiative none believed themselves to be in the second 
stage, learning the process, or in the third stage, understanding and applications. The problems with selfreporting are well known, however, the results of the surveys indicate growth in both comfort and confidence among the faculty participants.

\section{Insight 4}

\section{Small group conversations and continuous interaction positively impact the de- sign of professional development.}

Lieberman (2000) defines professional development as a practice that, instead of pushing teachers to become consumers of canned knowledge, pushes teachers to reinvent their practice by integrating new knowledge and new technologies in designing learning activities. Successful professional development experiences are those centered in concrete and contextualized teaching experiences with opportunities to collaborate and dialogue with peers and experts (Little, 1993). We believe professional development must be a practice that offers meaningful intellectual, social, and emotional engagement with ideas, with materials, and with colleagues.

Time and space for sustained discussions are vital for continued individual and collective growth, yet are rare in both K-12 settings and in colleges of education. Our professional development included reflective discussions of theoretical research and of practitioner examples of technology integration. Once a month, faculty participated in group discussions of selected books and articles focused on practical and theoretical concerns, and on social, ethical, legal and human issues surrounding the use of technology. These monthly discussions of educational technology readings provided occasions for faculty to explore the potential of computer-based technologies in enhancing instructional strategies and to articulate their knowledge, reasoning, and problem-solving processes with colleagues. Discussion time incorporated into each workshop provided additional opportunities to focus on ways to integrate the software into content disciplines by exploring the affordances of various pieces of software. These group discussions enabled the faculty to compare their insights, concerns, and strategies with those of the Professional Development Coordinator, Tech Guides, and other faculty participants.

\section{Insight 5}

\section{Each faculty member's philosophy of education and teaching style must be re- spected in the process of integrating technology.}

The guiding principle of our professional development was the intention that any changes in teacher education in our college would come through our faculty, not to them. This meant that each Tech Guide had to create a connection to each faculty participant. Support was tailored to individual faculty and redirected or constructed during the interactions.

Some faculty participants reacted to technology integration in surprising ways. It is reasonable to assume that early childhood educators would be skeptical about the place of technology in teacher preparation while science educators would eagerly embrace technology integration. Following are statements from two faculty members illustrating the importance of learning about and respecting each person's philosophy of education and teaching style.

Technology heightens our awareness of children's' play because it gives us multiple tools for recording and documenting children's' work and play. As adults, we can increasingly understand and appreciate children's play as we become keener observers of their actions and behaviors as they go about their daily activities. (Baji, Early Childhood Education)

I've seen technology used in schools and I hear my teachers talk at the masters level. And, 
it just seems like it becomes-computers have become textbooks on screens. And then there is a whole lot less of the thinking skills and synthesis level work and the creativity being done with teachers in the classroom. That's the main reason that I've skipped it [technology integration]. Because I feel a lot of it is textbooks on screens. I want to get past that. (Quincy, Science Education)

In these two cases, the early childhood educator used video extensively to capture children's play. She and her students studied these videos to see actions and interactions too ephemeral to be seen in real time. They used the videos to create PowerPoint presentations illustrating theories of child development. She and her students pushed her Tech Guide to learn new skills and to think about the potential for technology in early childhood education in new ways. The science educator, on the other hand, was quite resistant to technology. She felt it made abstract concepts that children should experience physically. After much experimenting and conversation, she and her Tech Guide found ways to use tool software that fit her philosophy and teaching style.

The commitment of the Tech Guides to stay with Shared Visions throughout the grant period became crucial in establishing and maintaining personal relationships for individualized support. Over time, Tech Guides discovered different ways to reach each faculty member. They understood the teaching styles of the faculty participants making it easier to suggest software, hardware, or activities that supported the preferred instructional strategies of each faculty member.

\section{Insight 6}

\section{Incentives promote interest and motivation, but institutional pressures will con- tribute to lack of participation.}

We were very conscious of the importance of incentives and motivation for the success of our project. Incentives for the faculty participants included cash stipends, laptop computers and software, and ondemand professional assistance. In accordance with our plan to co-design the professional development as our work together unfolded, we continually sought input from the faculty participants, provided them with long-term support, and redesigned activities to best suit the faculty in our struggle to encourage and maintain motivation. Despite our best efforts, at least one-third of the faculty participants rarely scheduled meetings with their Tech Guide or failed to keep scheduled appointments.

At the beginning of every semester, several faculty members would voice their renewed commitment to take advantage of Tech Guides' services, workshops, and reading discussions. By mid-semester, these and other faculty participants were apologizing for missing grant activities citing teaching responsibilities, meetings, or crises with students as the culprits. Nearly all of them remarked on feeling regret for not participating as fully as they intended. Several faculty members offered to return the laptops. Some refused the semester's cash stipend.

When questioned about the lack of participation on their parts, the faculty repeatedly cited time as their major obstacle to participation.

"I don't have enough time to do extra projects, and so it always goes to the bottom of my list." (Leila, Bilingual Education)

"Time, maybe time is number one; just time to think about it, work on it, and do it instead of always running. I feel like a lot of times I am always running to do what needs to be done the next day. Because of the crises." (Linda, Secondary Teacher Education)

We interpret time as the dominance of institutional pressures that took priority for our participants. As approximately $50 \%$ of the faculty involved in Shared Visions were tenure track junior faculty, the pressure to publish was palpable. We encouraged the faculty participants to use this professional development ex- 
perience as a research opportunity and suggested that they collaborate with one another or us on manuscripts and conference presentations. Some did this while others concentrated on lines of research established prior to Shared Visions.

Incentives did inspire initial interest. As the grant progressed, incentives became a source of guilt for some faculty participants as institutional responsibilities left little time and energy for learning new pieces of software that may or may not be appropriate in their teaching.

\section{Suggestions for Sustaining the Process}

Our experiences during the Shared Visions project point to several ways of sustaining professional development in the area of technology integration for teacher education faculty. These include administrative support over a long period of time; a professional development coordinator who comes from the teacher education faculty; and graduate students with teaching experience who are committed to learning new technologies and to working out collaborative relationships with faculty members.

The importance of administrative leadership in the change process has been well documented for many years (Goodlad, 1968; Lieberman, 1973). Deans and department chairs must be supportive of reallocating funds and faculty responsibilities. Shared Visions serves as a model for institutionalizing a professional development team. A faculty member in education with classroom teaching experience, a background in pedagogy, and experience with multiple pieces of hardware and software could be given a course reassignment to work with a team of graduate students similar to the Tech Guides.

Since time is always at a premium for faculty, we suggest that faculty members be given a course reassignment to work on technology skills and on redesigning methods courses. Faculty receiving course releases would work with graduate students to explore various technologies with the expectation that appropriate hardware and software would be integrated into teacher education courses. These experiences could serve as the basis for publications and conference presentations. Over time, a pool of faculty with technology integration experience could serve a resource to other faculty attempting to integrate technology.

Repeatedly, our faculty participants emphasized the importance of the Tech Guide's teaching experience. The ability of both the faculty member and the Tech Guide to "think like a teacher" when planning technology integration activities made the partnerships stronger. The team of graduate students working with the faculty professional development coordinator should come from across teacher education graduate programs in the college. The team, including the professional development coordinator, would be responsible for gaining new technology skills and exploring hardware and software with potential in K-12 learning environments.

Graduate students' work with teacher education faculty might take two forms. Our model of one graduate student supporting several faculty members worked well. Another alternative would be to assign the graduate students as co-teachers of methods courses with faculty members. Their responsibility to the course would be the integration of technology. Their responsibility to the faculty member would be to assist them in learning to use hardware and software with the goal of achieving autonomy over a one- or two-year time period. The sustained support from a graduate student who knew their teaching styles, content areas, and philosophical foundations contributed to the success of our faculty participants.

Students as co-designers of technology integration proved to be as successful in teacher education as it was in the original high school setting for the Generation Y model. Tech Guides, working one-on-one with faculty participants, co-designed technology integration activities for teacher education courses, helped to carry out these activities in the classroom, and provided timely tutoring on software. Utilizing the reallocation of resources suggested here, this model of professional development would require only a small amount of actual funding.

Shared Visions offered our faculty numerous opportunities to learn multiple pieces of hardware and soft- 
ware. It also provided us many opportunities to explore with the faculty participants why they would use the hardware and software once they came to understand some of the affordances offered for improving instructional strategies. Together we wanted to explore how the hardware and software could impact student learning in various disciplines. Many of the faculty noted that they were just beginning to fully understand the potential of technology as a teaching and learning tool during the second half of the final year of our PT3 grant. Given that it takes approximately five years to become a technology-using teacher, these comments came as no surprise. We have just begun the process.

\section{References}

Cochran-Smith, M. \& Lytle, S. (1993). Inside/outside: teacher research and knowledge. New York: Teachers College Press.

Considine, D. (2000). Media literacy as evolution and revolution: in the culture, climate, and context of American education. In A. Watts Pailliotet \& P.B. Mosenthal (Eds.), Reconceptualizing Literacy in the Media Age, (pp. 299-327). Stamford, Connecticut: JAI Press Inc.

Generation YES. (2000). Retrieved March 8, 2002from the World Wide Web: http://www.genyes.org/

Goodlad, J. I. (1955). The individual school and its principal: Key setting and key person. Educational Leadership, 13 (1).

Hadley, M., and K. Sheingold. (1993). Commonalities and distinctive patterns in teachers' integration of computers. American Journal of Education , 101 (3), 261-315.

International Society for Technology in Education. (2000). National educational technology standards for teachers. Retrieved March 8, 2002 from the World Wide Web : http://cnets.iste.org/indes3.html

John-Steiner, V. (2000) Creative collaboration. New York: Oxford University Press

Johnston, M. (1997) Contradictions in collaboration. New thinking on school/university partnerships. New York: Teachers College Press.

Kerr, S. T. (1991). Lever and fulcrum: educational technology in teachers' thought and practice. Teachers College Record, 93(1), 114-136.

Lieberman, A. (1973). The power of the principal: Research findings. In C.M. Culver \& G.J. Hoban (Eds.). The power to change: Issues for the innovative educator. New York: McGraw Hill.

Lieberman, A. (2000). Networks as learning communities. Shaping the future of teacher development. Journal of Teacher Education , 51 (3):221-227.

Little, J. W. (1993). Teachers' professional development in a climate of educational reform. Educational Evaluation and Policy Analysis , 15 (2),129-151.

Rosenholtz, S. (1989). Teachers' workplace: The Social organization of Schools. New York: Longman.

Sandholtz, J. H, C. Ringstaff, and D. C. Dwyer. (1997). Teaching with technology: Creating student-centered classrooms. New York: Teachers College Press.

Sprinthall, N. A., A. J. Reiman, and L. Thies-Sprinthall. (1996). Teacher professional development. In J. Sikula (Ed.), Handbook of Research on Teacher Education, edited by. New York: Macmillan.

Stein, M. K., and E. A. Silver. (1999). The development of professional developers: Learning to assist teachers in new settings in new ways. Harvard Educational Review ,69 (3), 237-269.

U.S. Department of Education (2001). Timeline of educational technology milestones. Retrieved March 8, 2002 from the World Wide Web: http://www.pt3.org/technology/tech_timeline.html

Yocam, K. (1996). Teacher-centered staff development for integrating technology into classrooms. T.H.E. Journal , 24 (4), 88101.

\section{Biographies}

Leslie Hall is an assistant professor of educational technology at the University of New Mexico in Albuquerque, New Mexico. She served as the Professional Development Coordinator for the Shared Visions 
project. She has an M.A. and a Ph.D. in instructional design and technology from the Ohio State University. Her research is currently focused on professional development for faculty in colleges of education.

Clint Fisher is a doctoral candidate in the area of educational technology at the University of New Mexico. He served as a Tech Guide on the Shared Visions project. He has extensive experience working with preservice and inservice teachers in the area of technology integration. His current research looks at faculty conditions of work.

Sandra Musanti is a doctoral student in the area of language, literacy, and socio-cultural studies at the University of New Mexico. She served as a Tech Guide on the Shared Visions project. Sandra worked in professional development for special education teachers in her native country of Argentina before coming to the U.S. to pursue graduate studies.

Don Halquist is a doctoral student in the area of language, literacy, and socio-cultural studies at the University of New Mexico. He served as a Tech Guide on the Shared Visions project. He is a dancer and a graphic artist. His areas of academic interest include media and visual literacy and early childhood education.

Matt Magnuson is a doctoral student in the area of language, literacy, and socio-cultural studies at the University of New Mexico. He served as a Tech Guide on the Shared Visions project. He used his masters degree in ESL/bilingual education in his teaching in Ecuador. His interests include adult and community education, visual and media literacy, and computing as a second language.

Darcy Simmons-Klarer is a doctoral student in the area of organizational learning and instructional technologies at the University of New Mexico. She served as a Tech Guide on the Shared Visions project. She taught elementary school in Texas and New Mexico before beginning her doctoral studies. Her areas of interest are the design of effective interfaces and templates and professional development in technology integration. 